\title{
GD2 Lactone/GD3 Lactone-KLH Conjugate Bivalent Vaccine
}

National Cancer Institute

\section{Source}

National Cancer Institute. GD2 Lactone/GD3 Lactone-KLH Conjugate Bivalent Vaccine.

NCI Thesaurus. Code C74035.

A cancer vaccine, containing epitopes of the gang liosides GD2 and GD3 conjug ated with the immunostimulant keyhole limpet hemocyanin $(\mathrm{KLH})$, with potential antineoplastic activity. Vaccination with GD2 lactone/GD3 lactone-KLH conjug ate bivalent vaccine may elicit antibodies against tumor cells expressing either epitope, resulting in complementmediated cytotoxicity (CMC) and antibody-dependent cell-mediated cytotoxicity (ADCC). Located primarily in the nervous system, gangliosides, such as GD2 and GD3, are cell membrane components involved in cellular recog nition and cell-cell communication. 